\title{
Non-contiguous spinal tuberculosis
}

\author{
Deepwant Singh, Bhathiya Wijeyekoon \\ Department of Rheumatology, East and North Herts NHS Trust, Stevenage, Hertfordshire, UK
}

Correspondence to Dr Bhathiya Wijeyekoon, j.wijeyekoon@nhs.net

\section{DESCRIPTION}

A 26-year-old-man of Indian descent was referred to our rheumatology unit with 6 months of lower-back pain. He had lived in the UK for 5 years, travelling intermittently to holiday in India. His general practitioner detected a C-reactive protein of $55 \mathrm{mg} / \mathrm{l}$ and erythrocyte sedimentation rate of $95 \mathrm{~mm} / \mathrm{h}$ and referred with a possible 'spondyloarthritis'.

The patient gave a history of back pain with stiffness throughout the day. He admitted to fever, sweats and significant weight loss but denied having a cough.

On examination, he had slight limitation of lumbarspine-flexion with no focal spinal-tenderness or clinicalsacroilitis. Straight-leg-raise was $80^{\circ}$ bilaterally. Resisted hip-flexion caused exacerbation of lower-back pain. Power and knee-jerks were normal but ankle-jerks were reduced.

Chest-radiograph (figure 1) was normal and lumbarspine x-ray (figure 2) revealed a fifth lumbar-spine parsdefect only. Renal, liver and bone profile was normal. Three early-morning-urine samples, blood cultures and HIV-serology were negative.

Fevers, sweats, weight loss and reduced ankle-jerks are considered atypical for a spondylo-arthritis. Malignancy or indolent spinal infection form important differential diagnoses. An urgent MRI-spine (figure 3) revealed multiple spinal-lesions and a para-spinal-abscess eroding the

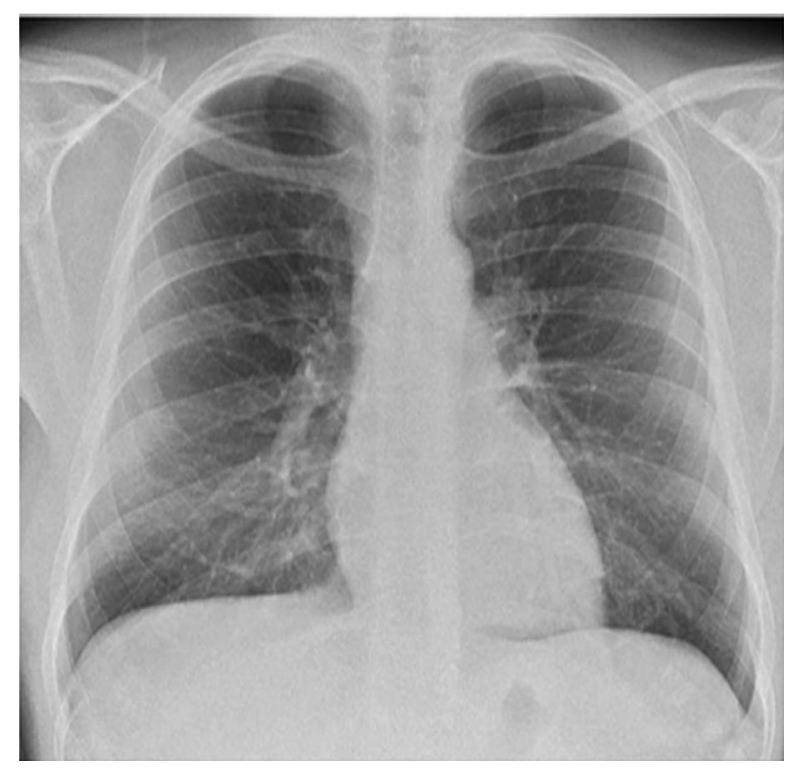

Figure 1 Chest radiograph was normal with no focal parenchymal lung pathology. sacrum. Subsequent CT demonstrated a left sixth-riblesion, the biopsy and histology of which revealed non-caseous-granulomas and negative acid-fast-bacilli stain. Culture of this specimen yielded Mycobacterium tuberculosis after 4 weeks.

About $23 \%$ of patients with spinal-tuberculosis (TB) may have normal spinal-plain-radiographs. ${ }^{1}$ Our case highlights the need for early spinal MRI in patients with suspected spinal TB, even when plain radiographs appear normal. TB-spondylitis frequently involves multipleadjacent spinal-vertebrae; non-contiguous vertebral involvement, as seen here, is relatively uncommon. ${ }^{2}$ Confusion with metastatic malignancy is possible; hence a tissue diagnosis is still essential. ${ }^{2}$

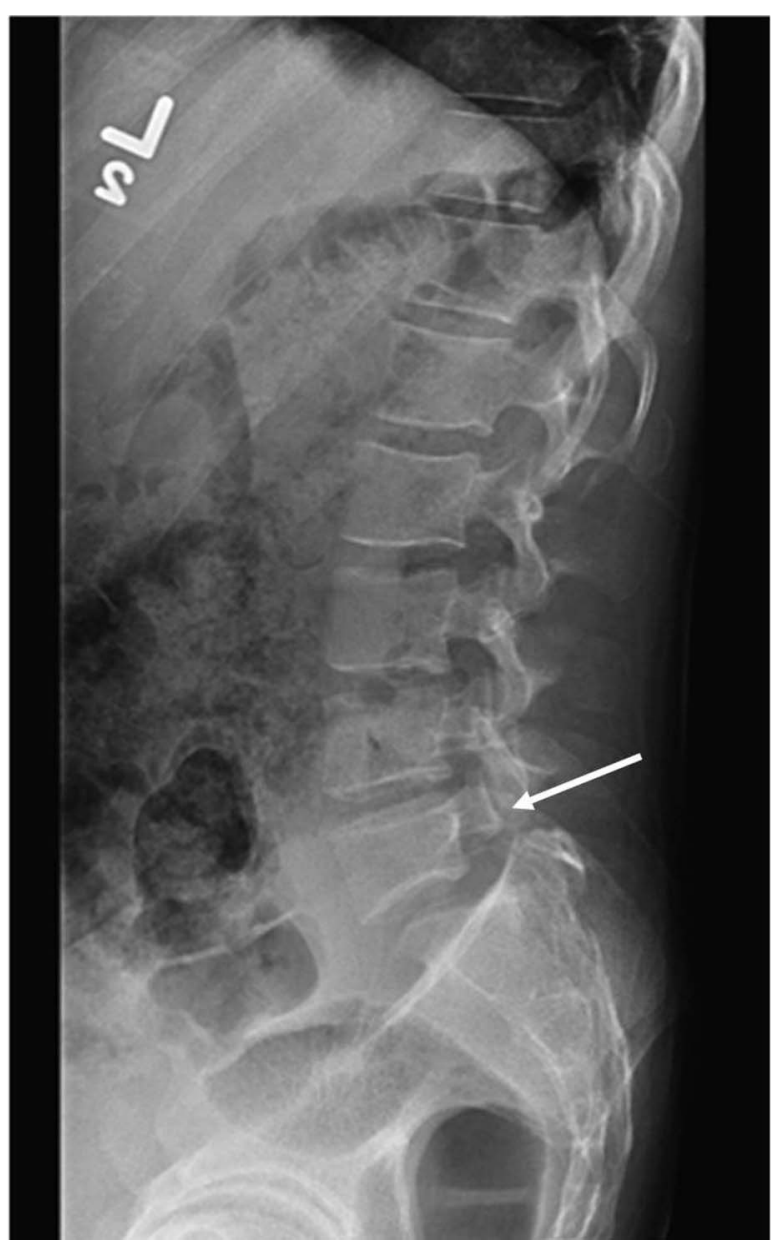

Figure 2 Lumbar spine $x$-ray demonstrating a fifth lumbar spine pars defect (white arrow). 


\section{BMJ Case Reports}

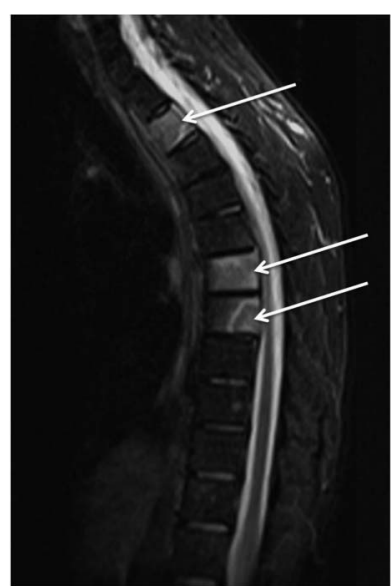

a

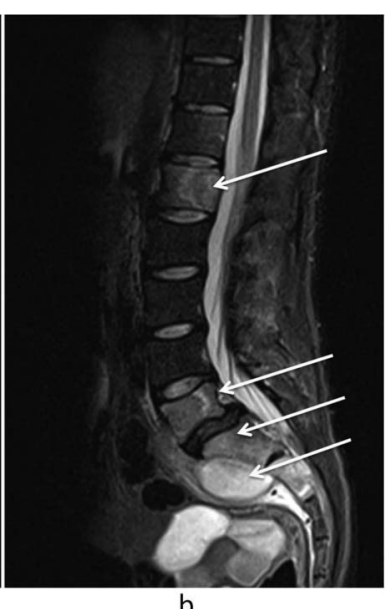

b

Figure 3 Sagittal MRI view of (A) thoraco-lumbar spine, (B) lumbo-sacral spine, demonstrating contiguous and non-contiguous spinal lesions as well as a $5.8 \times 3.7 \mathrm{~cm}$ presacral abscess (white arrows).

\section{Learning points}

In suspected cases of spinal tuberculosis (TB), early spinal imaging with MR is required, even if plain radiographs appear normal.

- A tissue diagnosis should be obtained whenever possible to exclude other pathologies (malignancy/infection) and to determine sensitivity to antituberculous treatment.

- Non-contiguous TB spondylitis is relatively uncommon but can be present even when plain radiographs appear normal, thus emphasising the need to MRI the whole spine.

Copyright 2012 BMJ Publishing Group. All rights reserved. For permission to reuse any of this content visit

http://group.bmj.com/group/rights-licensing/permissions.

BMJ Case Report Fellows may re-use this article for personal use and teaching without any further permission.

Please cite this article as follows (you will need to access the article online to obtain the date of publication).

Singh D, Wijeyekoon B. Non-contiguous spinal tuberculosis. BMJ Case Reports 2012;10.1136/bcr-2012-007382, Published XXX

Become a Fellow of BMJ Case Reports today and you can:

- Submit as many cases as you like

- Enjoy fast sympathetic peer review and rapid publication of accepted articles

- Access all the published articles

- Re-use any of the published material for personal use and teaching without further permission

For information on Institutional Fellowships contact consortiasales@bmjgroup.com

Visit casereports.bmj.com for more articles like this and to become a Fellow 